\title{
Economic Injury Level of the Neotropical Brown Stink Bug Euschistus heros (F.) on Cotton Plants
}

\author{
MF Soria ${ }^{1}$, PE Degrande ${ }^{1}$, AR PanizzI $^{2}$, MD Toews $^{3}$ \\ ${ }^{1}$ Lab of Applied Entomology and Biotechnology, Graduate Program in Agronomy, School of Agricultural Sciences, Federal Univ of Grande \\ Dourados, Dourados, MS, Brasil \\ ${ }^{2}$ Lab of Entomology, Embrapa National Wheat Research Center, Passo Fundo, RS, Brasil \\ ${ }^{3}$ Dept of Entomology, Univ of Georgia, Tifton, GA, USA
}

\section{Keywords}

Pentatomidae, sucking pest, attack, injury, damage, treatment threshold

\section{Correspondence \\ MF Soria, Lab of Applied Entomology and Biotechnology, Graduate Program in Agronomy, School of Agricultural Sciences, Federal Univ of Grande Dourados, Dourados, MS, Brasil; miguelagro@gmail. com}

Edited by Jorge B Torres - UFRPE

Received 13 March 2016 and accepted 13 October 2016

Published online: 14 November 2016

(C) Sociedade Entomológica do Brasil 2016

\begin{abstract}
In Brazil, the Neotropical brown stink bug, Euschistus heros (F.) (Hemiptera: Pentatomidae), commonly disperses from soybeans to cotton fields. The establishment of an economic treatment threshold for this pest on cotton crops is required. Infestation levels of adults of $E$. heros were evaluated on cotton plants at preflowering, early flowering, boll filling, and full maturity by assessing external and internal symptoms of injury on bolls, seed cotton/lint production, and fiber quality parameters. A completely randomized experiment was designed to infest cotton plants in a greenhouse with $0,2,4,6$, and 8 bugs/plant, except at the full-maturity stage in which only infestation with 8 bugs/plant and uninfested plants were evaluated. Results indicated that the preflowering, early-flowering, and fullmaturity stages were not affected by $E$. heros. A linear regression model showed a significant increase in the number of internal punctures and warts in the boll-filling stage as the population of bugs increased. The average number of loci with mottled immature fibers was significantly higher at 4,6 , and 8 bugs compared with uninfested plants with data following a quadratic regression model. The seed and lint cotton was reduced by 18 and $25 \%$ at the maximum level of infestation (ca. 8 bugs/plant) in the boll-filling stage. The micronaire and yellowing indexes were, respectively, reduced and increased with the increase of the infestation levels. The economic injury level of $E$. heros on cotton plants at the boll-filling stage was determined as 0.5 adult/plant. Based on that, a treatment threshold of 0.1 adult/plant can be recommended to avoid economic losses.
\end{abstract}

\section{Introduction}

The importance of stink bugs (Heteroptera: Pentatomidae) as pests of cotton in Brazil has increased in recent years due to the reduced use of broad-spectrum insecticides on the crop-a result from the success of regional suppression programs of the boll weevil (Anthonomus grandis Boh.) and widespread adoption of
Bt varieties by growers (Soria et al 2009, 2010a, Thomazoni et al 2010). A similar phenomenon occurred in the Southeast and Mid-South regions of the USA in the mid-1990s (Greene et al 1999, Haney et al 2009, Olson et al 2011), in which these two factors resulted in the rise of pentatomid pests, such as Euschistus servus (Say), Nezara viridula (L.), and Acrosternum (Chinavia) hilare (Say) to the status of key pests of cotton. 
In Brazil, among the three species of stink bugsEuschistus heros (F.), Edessa meditabunda (F.), and $N$. viridula, that infest cotton fields in the Cerrado regionthe first species is the most prevalent and of greater importance, as it is capable of causing significant damage to soybean and cotton (Soria et al 2009, 2010a, b, Thomazoni et al 2010). In the Brazilian Cerrado, cotton crops are grown in close proximity to soybean, and $E$. heros is the main pentatomid pest that infests soybean. Due to its ability of adapting to environmental conditions of the main row crop production regions and disperse from one host plant to another, regardless of whether the plants are cultivated or not (Panizzi 1997, 2000, Degrande \& Vivan 2008), this pest can be considered a threat to cotton crops in the Cerrado.

The dispersal ability of pentatomids in search of improving conditions for shelter, food, and reproduction (Panizzi \& Silva 2009) results in infestations of $E$. heros in Brazilian cotton fields. Long-cycle cotton varieties planted as a first crop or short/medium-cycle cotton varieties planted as a second crop just after soybean cultivation favor the dispersal of E. heros adults from maturing soybean crops to neighboring cotton crops (Soria et al 2009, 2010a). Some growers have reported extended infestations of cotton crops by stink bugs for a period lasting 30-40 days (FK, Mato Grosso Cotton Institute personal communication to MFS).

Normally, when a soybean crop enters the maturation/ harvesting stage, the adjacent cotton crops are in full bloom (boll-filling phase) and, therefore, susceptible to stink bugs (Willrich et al 2004a, Musser et al 2008). In the Southeastern USA, the 3 rd through the 5 th week is the most susceptible period for injury from stink bugs (Bacheler et al 2010); during this period, $>70 \%$ of the bolls are $<25$ days old (days after anthesis) or $\leq 25 \mathrm{~mm}$ in diameter, which is considered the size/age of bolls most susceptible to feeding injury from stink bugs (Herbert et al 2009).

When bolls suffer feeding injury and no abscission of these structures occurs, they develop cellular calluses ("warts") and show internal punctures in the mesocarp and, often, dark marks on the external exocarp (Wene \& Sheets 1964, Greene et al 1999, Toews et al 2009, Medrano et al 2011). Infestation by $E$. heros can result in a significant reduction $(60 \%)$ in the production of seed cotton and lint (Soria et al 2010b).

In the major cotton-producing regions of the USA, control of stink bugs in cotton is generally recommended when 1 bug/ $6 \mathrm{ft}$ is found using the beat sheet sampling method or when (on average) $20 \%$ of bolls, $\pm 2.5 \mathrm{~cm}$ in diameter, exhibit signs of internal damage (Greene et al 1999, 2001, 2006). However, recently, a dynamic treatment threshold, based on week of flowering, was established in which the percentage of bolls with a mean diameter of $2.5 \mathrm{~cm}$ showing any symptoms of internal injury is assessed has been widely adopted by North American cotton producers (Bacheler et al 2010).
Nevertheless, studies have been conducted to improve the determination of the treatment threshold using the assessment of symptoms of injury inside bolls of different sizes/ ages in the USA (Reay-Jones et al 2009, Toews et al 2009, Bacheler et al 2010).

In contrast, in Australia, control of stink bugs and plant bugs [Creontiades dilutus (Stål) and Creontiades pacificus (Stal) (Hemiptera: Miridae), N. viridula, and Piezodorus hybneri (Gmelin) (Hemiptera: Pentatomidae)] is implemented when an average of 0.5 bugs is found $/ \mathrm{m}^{2}$ (Ward 2005), showing the variability in recommendations depending on the country/location, environmental and farming conditions, as well as pest species.

Although preliminary studies in Brazil have detected the ability of Piezodorus guildinii (Westwood), N. viridula, and E. heros (Cruz-Júnior 2004, Soria et al 2009, 2010a) to cause injury and damage to cotton bolls, no study has determined the treatment threshold level of control and/or economic damage caused by these insects in Brazilian cotton. Specifically, E. heros, the main species of stink bugs found in the Brazilian Cerrado, should be closely investigated. Some treatment threshold recommendations, without a scientific basis, have been implemented, and this could result in unnecessary applications of insecticides, especially of organophosphates and pyrethroids, or in a late chemical treatment to avoid yield losses already occurring. Therefore, the present study reports, for the first time, the effects of different $E$. heros adult population levels on cotton. Seed and cotton lint production as well as fiber quality of Bt cotton plants (Bollgard ${ }^{\circledR}$ ) (Cry1Ac) in different phenological stages was assessed, providing an economic injury level (EIL) for this pentatomid on cotton crops in Brazil.

\section{Material and Methods}

\section{Study location}

The study was conducted using potted growth cotton plants cultivated in a greenhouse, from October 04, 2009, to May 19, 2010, at the Laboratory of Applied Entomology and Biotechnology ( $22^{\circ} 11^{\prime} 50.20^{\prime \prime S}, 54^{\circ} 55^{\prime} 58.90^{\prime \prime} \mathrm{W}$ at $459 \mathrm{~m}$ of altitude), School of Agricultural Sciences of Universidade Federal da Grande Dourados (UFGD), Dourados, MS, Brazil.

\section{Plant cultivation conditions}

Plants of the Bt variety NuOpal ${ }^{\circledR}$ Bollgard $^{\circledR}$ that express the Cry1Ac protein (Monsanto do Brasil Ltda., São Paulo, SP) were grown in pots with a 15-L substrate capacity. Initially, soil from the layer $60-80 \mathrm{~cm}$ in depth (Distroferric Red Latosol-"Latossolo Vermelho distroférrico-Lvdf") was sieved with a 2-mm sieve-mash and subsequently mixed with 
soil conditioner (Ribumin ${ }^{\circledR}$, Technes Agrícola, Cabreúva, SP) at a ratio of 10:1. In each pot, $11 \mathrm{~kg}$ of substrate (sieved soil and soil conditioner) was combined with $18 \mathrm{~g}$ of limestonetype filler, and the mixture was incubated for 40 days to promote the reaction of limestone with the soil that corrects the $\mathrm{pH}$ and $\mathrm{Al}$ toxicity before planting.

One day before sowing, $4 \mathrm{~g}$ of fertilizer formula 02-20-18 ( $\mathrm{N}-\mathrm{P}-\mathrm{K}+\mathrm{Ca}=9.0 \%$ and $\mathrm{S}=5 \%$ ) was added to each pot and homogenized with a gardening trowel. The amounts of limestone and fertilizer used were determined by considering the soil chemical analysis for soil correction and fertilizer application to cotton crops in the Cerrado (Beltrão et al 2002).

Sowing took place on December 7, 2009, in four holes (2 seeds/hole sown $2 \mathrm{~cm}$ deep) that were $8 \mathrm{~cm}$ apart in a symmetric square format. The seedlings were later thinned to two plants per pot. Prior to sowing, seeds were treated with the fungicides carbendazim and tiram (Derosal Plus ${ }^{\circledR}$, Bayer S.A., São Paulo, SP, carbendazim $0.3 \mathrm{~g} / \mathrm{kg}$ of seed $+0.7 \mathrm{~g}$ tiram $/ \mathrm{kg}$ of seed).

Pots were irrigated three times a week until the end of the plant cycle or until the time that the bolls were collected to assess the symptoms of injury. A volume of $1-2 \mathrm{~mL} / \mathrm{L}$ of the following insecticides was applied weekly with a pressurized hand sprayer, until run-off from the leaves: spiromesifen (Oberon $^{\circledR}$, Bayer S.A., São Paulo, SP, Brazil), pyriproxyfen (Tiger $^{\circledR}$, Sumitomo Chemical do Brasil Ltda., São Paulo, SP, Brazil), carbosulfan (Marshal $400 \mathrm{SC}^{\circledR}, \mathrm{FMC}$ Química do Brasil Ltda., Campinas, SP, Brazil), flonicamid (Turbine 500 WG ${ }^{\circledR}$, FMC Química do Brasil Ltda., Campinas, SP, Brazil), triflumuron (Certero ${ }^{\circledR}$, Bayer S.A., São Paulo, SP, Brazil), and abamectin (Abamex ${ }^{\circledR}$, Nufarm Indústria Química e Farmacêutica, S.A., Maracanaú, CE, Brazil). The applications took place to reduce infestations of whiteflies [Bemisia tabaci (Genn)], aphids (Aphis gossypii Glov), thrips [Frankliniella schultzei (Trybom)], spider mites [Tetranychus urticae (Koch)], and soybean looper [Chrysodeixis includens (Walk)].

To prevent Ramularia (Ramularia areola Atk) disease, weekly applications of $1-2 \mathrm{~mL} / \mathrm{L}$ of water with the fungicides azoxystrobin and cyproconazole (Priori $\mathrm{Xtra}^{\circledR}$, Syngenta Proteção de Cultivos Ltda., Paulínea, SP, Brazil) were performed in the same way as the insecticides were applied. All spraying of insecticides and/or fungicides was conducted within a minimum of 10 days between applications and infestations.

\section{Rearing conditions of insects}

Stink bugs used for infestation of plants were obtained from a colony maintained at the Applied Entomology and Biotechnology Laboratory at UFGD. Bugs were reared in an insect-rearing room maintained at constant photoperiod (14:10 L:D), temperature $\left(25 \pm 2^{\circ} \mathrm{C}\right)$ and relative humidity $(65 \pm 5 \%)$. Eggs, nymphs, and adults were kept in transparent plastic containers $(20 \times 30 \times 10 \mathrm{~cm})$ with a perforated lid covered with voile-type fabric and a base lined with filter paper. Sexing of adults was performed at $1-7$ days of age, and bugs were kept in groups of 20-25 couples to allow mating.

Adult bugs received a diet of green beans (Phaseolus vulgaris L.) and fruits of privet [(Ligustrum lucidum (Ait.)], supplemented with dried seeds from soybeans [Glycine $\max (\mathrm{L}$.)], peanuts (Arachis hypogaea L.), and sunflowers (Helianthus annuus L.). First instars were not fed, and 2nd to 5 th instars were fed green beans and privet fruit. Regardless of the stage of development, bean pods and privet fruits were replaced three times/week, while the dry seeds were replaced once a week.

Cotton rounds/pads used for skincare were placed inside the rearing containers with adults and served as a substrate for oviposition. Eggs were collected three times/week. Dirty containers were replaced with clean ones weekly. Before each plant development stage [preflowering-vegetative stage, early flowering, full flowering (boll filling), and full maturity-bolls opened] in which the levels of infestation of $E$. heros were tested, bugs were starved for $48 \mathrm{~h}$ and acclimated to the shady conditions of the environment.

For the infestations, a voile-type fabric cage $(1.00 \times 1.80 \mathrm{~m})$ covering each pot with the two plants was used to confine $E$. heros adults for 4 days with the plants. The 4-day period of infestation was defined based on the recommended pest scouting frequency to be performed in cotton fields at the main cultivation regions of the fiber in Brazil (Soria \& Degrande 2015). The rationale was based on the fact that if a grower decides to control the pest according to the observed in the current scouting and if no infestation was observed in the previous one, the pest had at least 4 days infesting the field.

Before infestation, the number of bolls was recorded, and boll diameters were measured with a digital caliper. Half of the adult specimens (aged 5-7 days) used in the infestations were males and half were females to equalize a possible difference in the abilities of the sexes to cause injury. Mortality of the bugs was assessed twice/day, and dead specimens were replaced when required.

\section{Experimental design and infestation procedures}

The completely randomized design was used considering the sources of variation of $E$. heros infestation level and cotton plant growth stage as fixed effects. Euschistus heros levels of infestation (0, 2, 4, 6, and 8 adults bugs/plant) were tested on the Bt (Cry1Ac) cotton plants in three different stages of development: (1) preflowering-vegetative stage, (2) early flowering, and (3) full flowering (or boll filling). At the fullmaturity stage-plants presenting bolls completely opened, only one infestation condition of 8 adults bugs/plant was evaluated in contrast with noninfested plants. 
Additional plants were grown to full flowering (boll filling) to allow the evaluation of injury inside the bolls by cracking them shortly after the period of infestation. The experimental unit or replicate was a pot with two plants. For each level of infestation, five pots were used for a total of 10 infested plants/treatment. In the full-maturity stage, 11 pots (replicates) were used for each treatment.

\section{Data assessment}

The effects of $E$. heros infestation levels on production parameters, fiber quality, and symptoms of injuries in bolls were assessed for each studied cotton plant growth stage. The numbers of loci with stained and rotten lint (hard locks) were assessed in bolls from infested and noninfested plants that were cultivated until the end of the cycle. The production of seed and lint cotton, as well as the fiber income (\%), was also evaluated.

Fiber quality (micronaire index, yellowness, and short fiber content) was evaluated through laboratory analysis using High Volume Instruments ( $\mathrm{HVI}$ ) equipment (Premier ART $2^{\mathrm{TM}}$, Premier Evolvics Pvt. Ltd., Coimbatore, India) on a cotton sample taken from two plants in each pot (replicate). For the full-flowering (boll-filling) stage, in which 50 additional plants were grown (two/pot) to assess symptoms of injury inside the bolls with destructive sampling, the parameters assessed were the following: (a) number of external marks (spots) on the exocarp, (b) number of internal punctures and callus growth ("warts") on the mesocarp, and (c) number of loci with immature fibers stained per boll.

\section{Statistical analysis}

For statistical analyses, all data parameters (symptoms of injury and damage to immature and mature bolls, cotton seed and lint production, and fiber income and quality) met the assumptions of normality and homogeneity of variance using the Shapiro-Wilk test, which was implemented in the UNIVARIATE procedure of SAS ${ }^{\circledR}$ (SAS Institute 2008). Thus, the original data were subjected to analysis of variance $(P \leq 0.05)$ using the GLM procedure of $\mathrm{SAS}^{\circledR}$ with subsequent regression analysis of the levels of infestation $(P \leq 0.05)$. Linear and nonlinear regression models were tested and one was selected based on the significance of the parameters and on the highest coefficient of determination $\left(R^{2}\right)$ values observed by using the REG procedure of SAS ${ }^{\circledR}$ (SAS Institute 2008). In the case of the full maturation stage, only the analysis of variance was performed, as only two treatments were tested.

The EIL was established based on the formula proposed by Gallo et al (2002): EIL $(\%)=C \times 100 / V$, where $C=$ pest control (treatment) cost in US $\$ /$ ha and $V=$ value of the production in US $\$ /$ ha, which represents the maximum loss acceptable by the pest in \%. That determination was based on the cotton lint yield potential of the noninfested plants ( 0 adult bugs/plant) according to the regression model selected, by extrapolating to the most common plant density used in a cotton crop hectare in Brazil (100,000 plants). The EIL in $\%$ was then transformed to bugs per plant according the maximum cotton lint yield reduction allowed in $\%$ using the regression model selected.

Information regarding the cost of control (insecticide and application cost) and on production value were obtained from CONAB (2012) and Quintana (2013).

\section{Results}

\section{Number and diameters of bolls}

Bolls were obtained only in the early-flowering (EF) and fullflowering (boll-filling) [FF (BF)] stages. The plants infested at EF showed an average number and diameter of bolls of approximately 1.7 and $11.0 \mathrm{~mm}$, respectively (Table 1), with squares and flowers being observed. In the full-flowering (FF) stage, plants showed a number of bolls and mean boll diameter of approximately 6.5 and $26.5 \mathrm{~mm}$, however, with no squares and flowers being observed. The FF stage was characterized by the cutout event where flower development ceases (Ritchie et al 2007).

\section{Stink bug attack symptoms and injuries on bolls and fiber quality}

None of the parameters evaluated at the end of the plant cycle were affected by the $E$. heros infestation levels tested in the preflowering (PF) stage (Table 2). Only the yellowness index showed a significant response in the EF stage. On the

Table 1 Number and average diameter ( \pm standard deviation) of bolls from Bt cotton plants at three stages of development used for tests with different levels of Euschistus heros infestation (0, 2, 4, 6, and 8 adults stink bugs/plant). 2009/2010 growing season. Dourados, MS, Brazil, 2012.

\begin{tabular}{lll}
\hline Development stage & Number of bolls & Boll diameter $(\mathrm{mm})$ \\
\hline Preflowering & $-^{\mathrm{a}}$ & - \\
Early flowering & $1.7 \pm 0.67$ & $10.9 \pm 3.31$ \\
Full flowering/boll filling (I) $^{\mathrm{b}}$ & $6.4 \pm 1.37$ & $26.2 \pm 1.28$ \\
Full flowering/boll filling (II) $^{\mathrm{b}}$ & $6.3 \pm 1.38$ & $26.9 \pm 2.51$ \\
\hline
\end{tabular}

${ }^{a}$ Development stage without bolls.

${ }^{\mathrm{b}}$ Full-flowering or boll-filling stage $(I)=$ bolls were maintained on plants after infestation for the evaluation of production parameters and fiber quality, and (II) = bolls were removed from the plants after infestation to evaluate symptoms of attack and injury. Average of 50 plants (10 plants per level of infestation). 
Table 2 Significance of $F$ test from analysis of variance for injury, yield, and fiber quality parameters studied at different stages of development of cotton plants in response to different levels of Euschistus heros infestation (0, 2, 4, 6, and 8 adults stink bugs/plant). $2009 / 2010$ growing season. Dourados, MS, Brazil, 2012.

\begin{tabular}{|c|c|c|c|c|c|c|c|c|c|}
\hline \multirow[t]{3}{*}{ Parameter and coefficient of variation } & \multicolumn{9}{|c|}{ Development phase } \\
\hline & \multicolumn{3}{|c|}{ Preflowering } & \multicolumn{3}{|c|}{ Early flowering } & \multicolumn{3}{|c|}{ Boll filling } \\
\hline & d.f. & $F$ & $P$ & d.f. & $F$ & $P$ & d.f. & $F$ & $P$ \\
\hline Diseased locules (PDL) & 4 & 1.17 & 0.35 & 4 & 1.14 & 0.36 & 4 & 14.19 & $<0.01$ \\
\hline CV (\%) & & 60.23 & & & 56.21 & & & 26.73 & \\
\hline Seed cotton (PSC) & 4 & 0.03 & 0.99 & 4 & 0.17 & 0.95 & 4 & 2.46 & 0.07 \\
\hline CV (\%) & & 11.69 & & & 20.17 & & & 14.58 & \\
\hline Lint cotton (PLC) & 4 & 0.16 & 0.95 & 4 & 0.51 & 0.72 & 4 & 3.58 & 0.02 \\
\hline CV (\%) & & 13.45 & & & 12.28 & & & 15.54 & \\
\hline Lint production (LP) & 4 & 0.91 & 0.47 & 4 & 0.14 & 0.96 & 4 & 3.64 & 0.02 \\
\hline CV (\%) & & 3.79 & & & 27.41 & & & 5.21 & \\
\hline Fiber strength (FS) & 4 & 0.63 & 0.64 & 4 & 0.70 & 0.59 & 4 & 0.09 & 0.98 \\
\hline CV (\%) & & 3.61 & & & 3.90 & & & 5.04 & \\
\hline Micronaire index (MI) & 4 & 1.49 & 0.24 & 4 & 1.22 & 0.33 & 4 & 3.04 & 0.04 \\
\hline CV (\%) & & 7.02 & & & 8.85 & & & 11.08 & \\
\hline Yellowness (+b) & 4 & 0.85 & 0.51 & 4 & 4.16 & 0.01 & 4 & 5.68 & $<0.01$ \\
\hline CV (\%) & & 12.99 & & & 9.45 & & & 11.25 & \\
\hline Short fibers (w) & 4 & 0.59 & 0.67 & 4 & 1.15 & 0.36 & 4 & 3.38 & 0.02 \\
\hline CV (\%) & & 12.91 & & & 18.56 & & & 15.09 & \\
\hline
\end{tabular}

$P D L$ percentage of diseased locules per boll, $P S C$ production of seed cotton (g) per plant, $P L C$ production of lint cotton (g) per plant, $L P$ lint production (\%) after seed cotton ginning, FS fiber strength (g/tex), $M I$ micronaire index (dimensionless), $+b$ degree of yellowing, $w$ content of short fibers (\%), $C V$ coefficient of variation (\%).

other hand, during either the FF or the BF stages, symptoms of boll damage and injury just after the infestation period (number of external signals [spots] on the exocarp, number of internal punctures and cell calluses ["warts"] on the mesocarp, and number of loci with immature stained fibers/ boll) were significantly affected by $E$. heros infestation level (Table 3).

A significant positive linear relationship between the level of infestation and the number of internal punctures $\left(r^{2}=0.976\right)$ and cell calluses $\left(r^{2}=0.798\right)$ was observed in the mesocarp, with 7.3-fold increase in the number of internal punctures and 7.6-fold increase in the number of cell calluses at the maximum level of bugs tested/plant (Fig 1a, b). The number of internal punctures and cell calluses ranged from 0.13 to 9.52 and 0.21 to 1.61 , respectively, depending on the tested infestation level (o to 8 bugs/plant). The percentage of loci with immature stained lint represented a significant quadratic regression model $\left(R^{2}=0.939\right)$, with a maximum percentage of hard loci being reached at the maximum level of 6 bugs/plant. An 8-fold increase in the number of loci with immature stained lint was observed at this infestation level compared with the level of o bugs/plant (Fig 1c). The number of external punctures observed/loci exhibited a polynomial pattern, increasing in the treatments up to 6 bugs/plant and decreasing at 8 bugs/plant. However, the polynomial model was not significant $(P>0.05)$ (Fig 1d).

The number of hard loci increased significantly in relation to $E$. heros infestation levels, showing significant positive $\left(r^{2}=0.916\right)$ linear growth (Fig 1e). The percentage of hard loci/boll increased by almost 1.5-fold in the first level of infestation ( 2 bugs/plant) and reached a maximum increase of

Table 3 Values of $F$ test from analysis of variance for attack and injury parameters of Euschistus heros at the full-flowering (boll-filling) stage of Bt cotton plants for different levels of infestation $(0,2,4,6$, and 8 adult stink bugs/plant). 2009/2010 growing season. Dourados, MS, Brazil, 2012.

\begin{tabular}{llll}
\hline Parameters & \multicolumn{3}{l}{ Full-flowering phase $($ d.f. $=4)$} \\
\cline { 2 - 4 } & $F$ & $P$ & CV (\%) \\
\hline External punctures (EP) & 5.32 & $<0.01$ & 51.15 \\
Internal punctures (IP) & 17.18 & $<0.01$ & 41.92 \\
Cell callus (CC) & 4.57 & $<0.01$ & 70.82 \\
Stained fibers (PLMIF) & 16.59 & $<0.01$ & 28.64 \\
\hline
\end{tabular}

$E P$ number of dark stains (spots) in the mesocarp per locule, IP number of puncture signs on the endocarp per locule, $C C$ number of cell calluses ("warts") on the endocarp per locule, PLMIF percentage of locules with mottled immature fibers per boll, CV coefficient of variation (\%). 

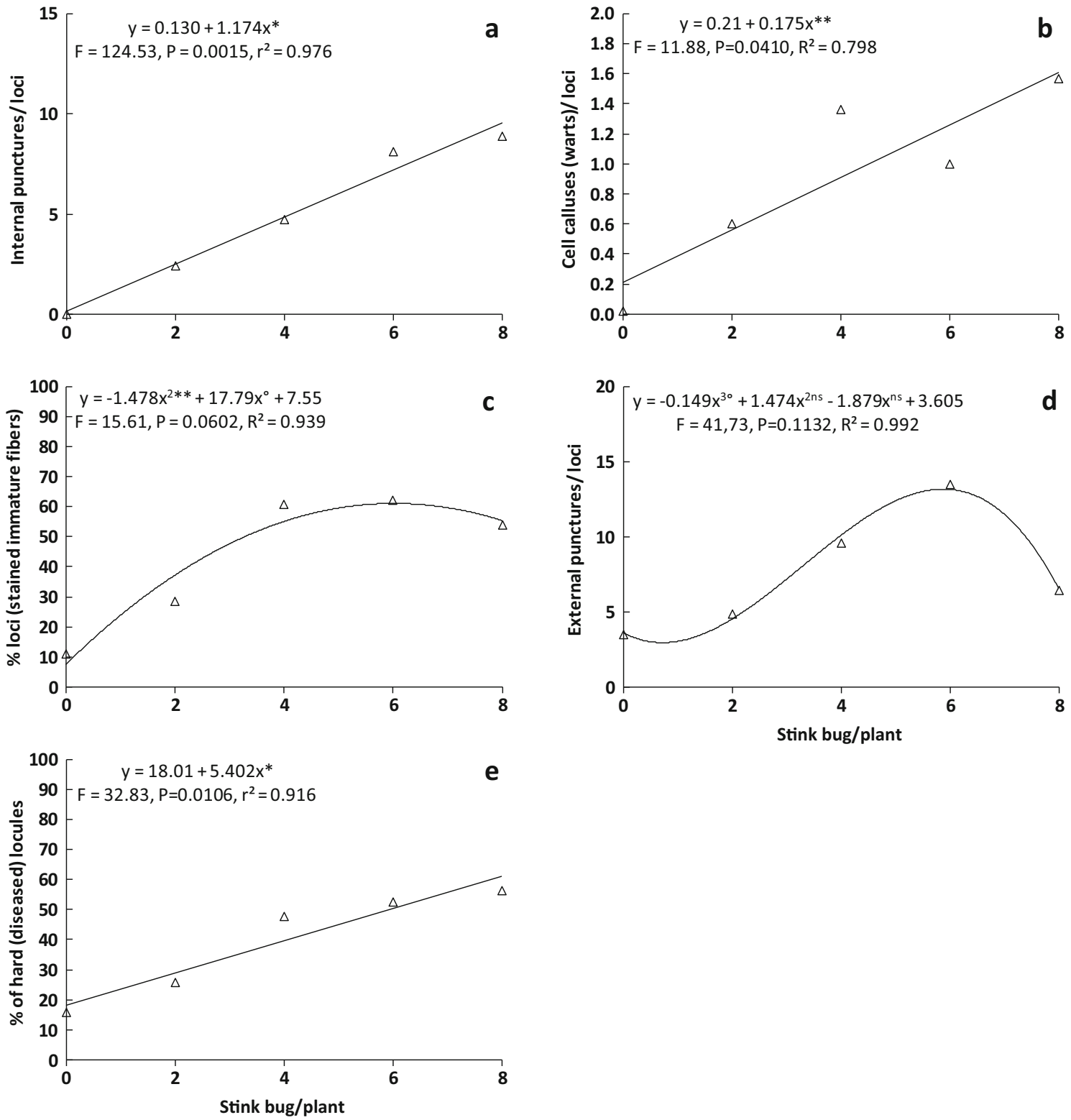

Fig 1 Symptoms of attack and injury by Euschistus heros [a number of signs of internal punctures on the endocarp, b number of cell calluses ("warts") on the endocarp, c percentage of locules with mottled immature fibers per boll, $d$ number of dark marks (spots) on the mesocarp, and e percentage of diseased locules per boll] on cotton plants infested with $0,2,4,6$, and 8 adult bugs during the full boll-filling phase $(n=5)$. 2009/2010 growing season.

3.4-fold at the highest level of infestation (8 bugs/plant). This increase of almost $34 \%$ at the maximum level of infestation relative to uninfested plants resulted in $61 \%$ of bolls presenting symptoms of hard locule. However, without infestation, $18 \%$ of the bolls were incompletely opened (Fig 1e).

In the EF stage, the yellowness index best fit a linear regression model $\left(r^{2}=0.7352\right)$, with at least two of the infestation levels favoring a higher degree of fiber yellowness compared with the noninfested level (Fig 2).

The FF stage showed the highest susceptibility to $E$. heros injury. In this stage, most parameters were significantly altered in response to $E$. heros infestation, including the number of locules with immature stained lint, lint cotton production, lint yield, micronaire index, yellowness (+b), and short fiber content (w) (Fig 3). Regarding fiber quality parameters in the FF stage, the micronaire index showed significant negative linear reduction $\left(r^{2}=0.834\right)$ and ranged from 3.62 to 4.42 relative to no infestation (zero) and the maximum number of bugs/plant (eight adults) (Fig 2a). The degree of yellowness (+b) fits a quadratic regression model, with the largest values (peaks) obtained at the level of infestation of 6 bugs/plant (Fig 2b). These values of yellowing ranged from 6.1 (o bugs/plant) to 

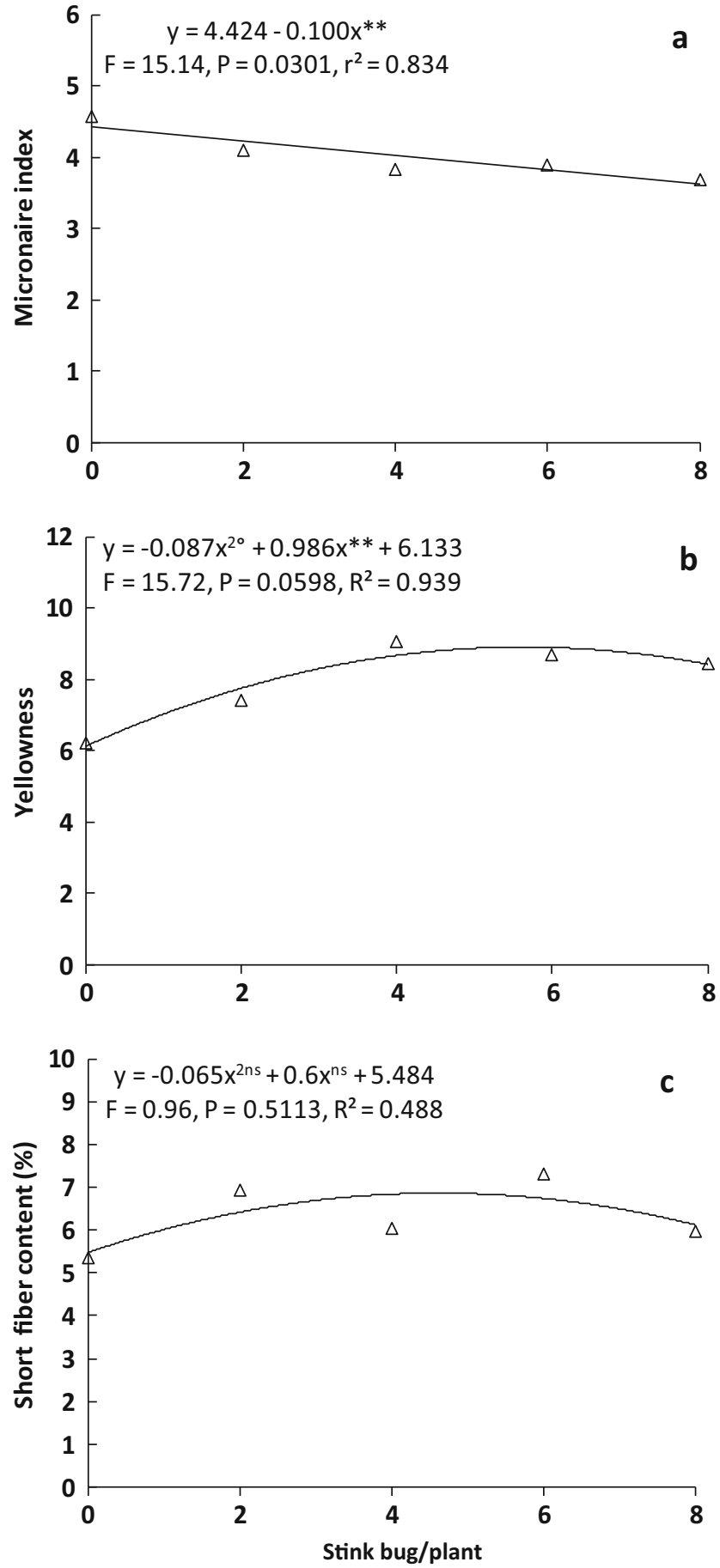

Fig 2 Micronaire index (a), short fiber content (b), and degree of yellowing (c) of fibers of Bt cotton plants infested with $02,4,6$, and 8 Euschistus heros adults in the full-flowering phase $(n=5) .2009 / 2010$ growing season. Dourados, MS, Brazil, 2012. Regression coefficients: ${ }^{*} P \leq 0.01,{ }^{* *} P \leq 0.05,{ }^{\circ} P \leq 0.10, n s$ not significant.

8.9 ( 6 bugs/plant). Likewise, the quadratic regression model was the most appropriate for the parameter percentage of short fibers (w); however, it lacked significance at the predetermined level ( $P>0.05$ ) (Fig 2c).
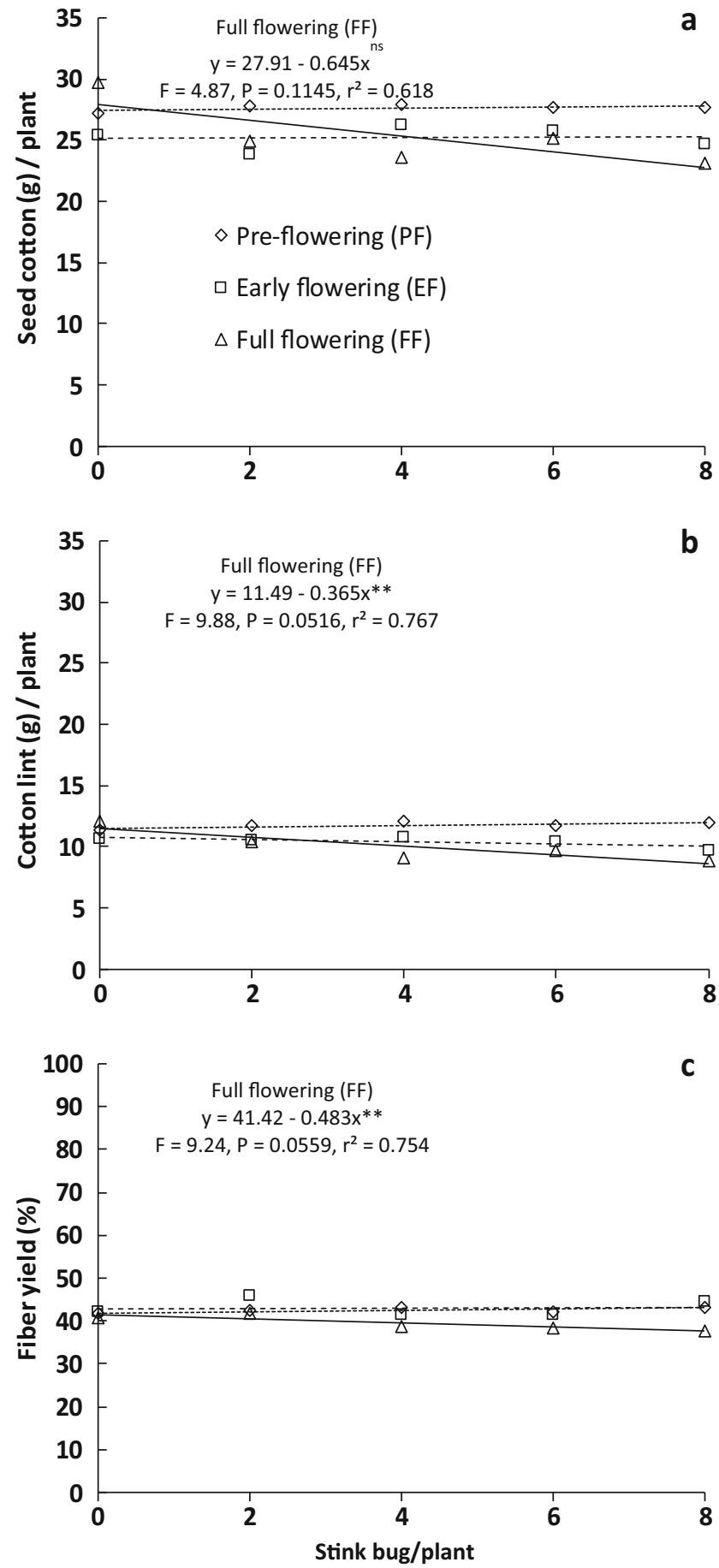

Fig 3 Production of seed cotton (a), lint (b), and average fiber yield (c) of cotton plants infested with $0,2,4,6$, and 8 adult Euschistus heros bugs in the preflowering (PF), early-flowering (EF), and boll-filling (BF) phases $(n=5) .2009 / 2010$ harvest. Dourados, MS, Brazil, 2012. Only the variables lint production (II) and fiber yield (III) during the boll-filling

When the plants were infested with all bolls opened (full maturity stage), infestation by adults of $E$. heros did not significantly affect any of the parameters evaluated (Table 4). 
Table 4 Significance of $F$ test from analysis of variance for cotton plant injury, production, and quality parameters studied at the stage of full maturity (harvest) as a function of the infestation by Euschistus heros ( 8 adults of stink bugs/plant). 2009/2010 growing season. Dourados, MS, Brazil, 2012.

\begin{tabular}{llll}
\hline Parameter and coefficient of variation & \multicolumn{3}{l}{ Full-maturity stage $($ d.f. $=1)$} \\
\cline { 2 - 4 } & $F$ & $P$ & $\mathrm{CV}(\%)$ \\
\hline Diseased locules (PDL) & 0.54 & 0.47 & 62.26 \\
Seed cotton (PSC) & 0.56 & 0.46 & 13.68 \\
Lint cotton (PLC) & 0.06 & 0.80 & 11.21 \\
Lint production (LP) & 0.37 & 0.54 & 10.64 \\
Fiber strength (FS) & 0.37 & 0.54 & 3.70 \\
Micronaire index (MI) & 0.22 & 0.64 & 10.30 \\
Yellowness (+b) & 0.57 & 0.45 & 11.66 \\
Short fibers (w) & 1.07 & 0.31 & 19.07 \\
\hline
\end{tabular}

PDL percentage of diseased locules per boll, $P S C$ production of seed cotton (g) per plant, $P L C$ production of lint cotton (g) per plant, $L P$ lint production (\%) after seed cotton ginning, FS fiber strength (g/tex), MI micronaire index (dimensionless), $+b$ degree of yellowing, $w$ short fiber content (\%), CV coefficient of variation (\%).

\section{Seed and lint cotton production}

The production of cotton seed was not affected at 0.05 level of significance. Despite lacking statistical relationship from infestation level, the production of seed cotton ranged from $4.6 \%$ (1.29 g) at the lowest level of infestation (o bugs/plant) to $18.4 \%$ (5.16 g) at the highest level (8 bugs/plant) (Fig 3a).

The production of seed and lint cotton from infested plants in the PF and EF stages did not differ between the tested levels of infestation. The production of lint cotton $\left(r^{2}=0.767\right)$ and fiber income $\left(r^{2}=0.754\right)$ were affected only during the FF stage, with a significant linear decrease in both production parameters (Fig 3b, c). The reduction in the production of lint cotton per plant ranged from 6.3 (0.73 g) to $25.4 \%$ (2.92 g) between 0 and 8 bugs/plant. For the fiber income, this reduction ranged from 2.3 to $9.3 \%$.

\section{Economic injury level}

The calculation of EIL was based on the linear regression obtained for the reduction in the production of lint cotton model because the regression model obtained for this variable in this study was statistically significant at $10 \%$ significance $(P=0.0516)$. EIL to $E$. heros was established to the full flowering (boll filling) (FF [BF]), and once at that stage, the plants showed susceptibility to the infestation levels tested. Based on the calculation used to determine the $E$. heros EIL, which depended on the variables adopted and the regression equation obtained in this study for the production of seed cotton, the value obtained to adopt any chemical to control $E$. heros on cotton crops, which means, the treatment thresholds at the FF stage ( 6.5 bolls/plant with an average diameter of $26.5 \mathrm{~mm}$ ) were 0.5 brown stink bug adults per plant (Table 5).

The EIL may vary due to changes in the values and costs of crop production and may be revised based on the information generated in this study. For example, alterations may be made using the equation for the production of seed cotton yield or even that for fiber quality parameters.

\section{Discussion}

This study showed for the first time that $E$. heros, the Neotropical stink bug, is capable of causing economic damage to cotton crops, particularly when plants are at the bollfilling stage (full flowering), with an average fruit diameter of approximately $25 \mathrm{~mm}$. Bolls of this diameter are preferred and have increased susceptibility to injury by phytophagous stink bugs (Siebert et al 2005, Toews et al 2009). Therefore, plants at this stage of development are more susceptible than those at the preflowering and/or full-maturity stages, in which the infestation did not affect the parameters evaluated.

For cotton fields in the USA, the period from the second to sixth week of flowering has the highest incidence of stink bugs (Bacheler et al 2010). During this period, most of the bolls (between 50 and 100\%) are smaller or equal to $25 \mathrm{~mm}$ in size, and the dynamic treatment threshold, which is based on the percentage of bolls with injury by week of bloom, is the lowest within this period (Herbert et al 2009, Bacheler et al 2010), which highlights the susceptibility of cotton to these insects during these stages of development and agrees with our results.

As was also detected for the different infestation levels tested in this study, the cotton preflowering stage, where flower buds are predominant, was not susceptible to attack by $E$. servus or N. viridula (Willrich et al 2004b). However, persistent infestations of $N$. viridula nymphs in plants with flower buds may result in the abscission of these structures, hence resulting in yield reduction (Willrich et al 2004b). Abscission also occurs in bolls smaller than or equal to $25 \mathrm{~mm}$ when they are attacked by either nymphs or adults (Cruz-Júnior et al 2003, Cruz-Júnior 2004, Bommireddy et al 2007, Soria et al 2010b). However, in the present study, the parameters evaluated during early flowering (bolls with a mean diameter of $11 \mathrm{~mm}$ ) were not affected by the different population levels of $E$. heros adults evaluated.

This observation indicated that the abscission of attacked fruits (flower buds or bolls) in pre- or early-flowering stages was not sufficient to affect the production parameters, or the plant was able to compensate for the loss of these structures, as cotton plants naturally abort a percentage of their structures during the flowering period (Ritchie et al 2007). 
Table 5 Economic injury level (EIL) established for Euschistus heros on Bt cotton during the boll-filling phase (BF) or full flowering (FF), depending on the cost of production and the cropping system considering the Rondonópolis region, in Mato Grosso (MT), Brazil, and the linear decrease equation in the cotton lint production obtained per plant. Dourados, MS, Brazil, 2012.

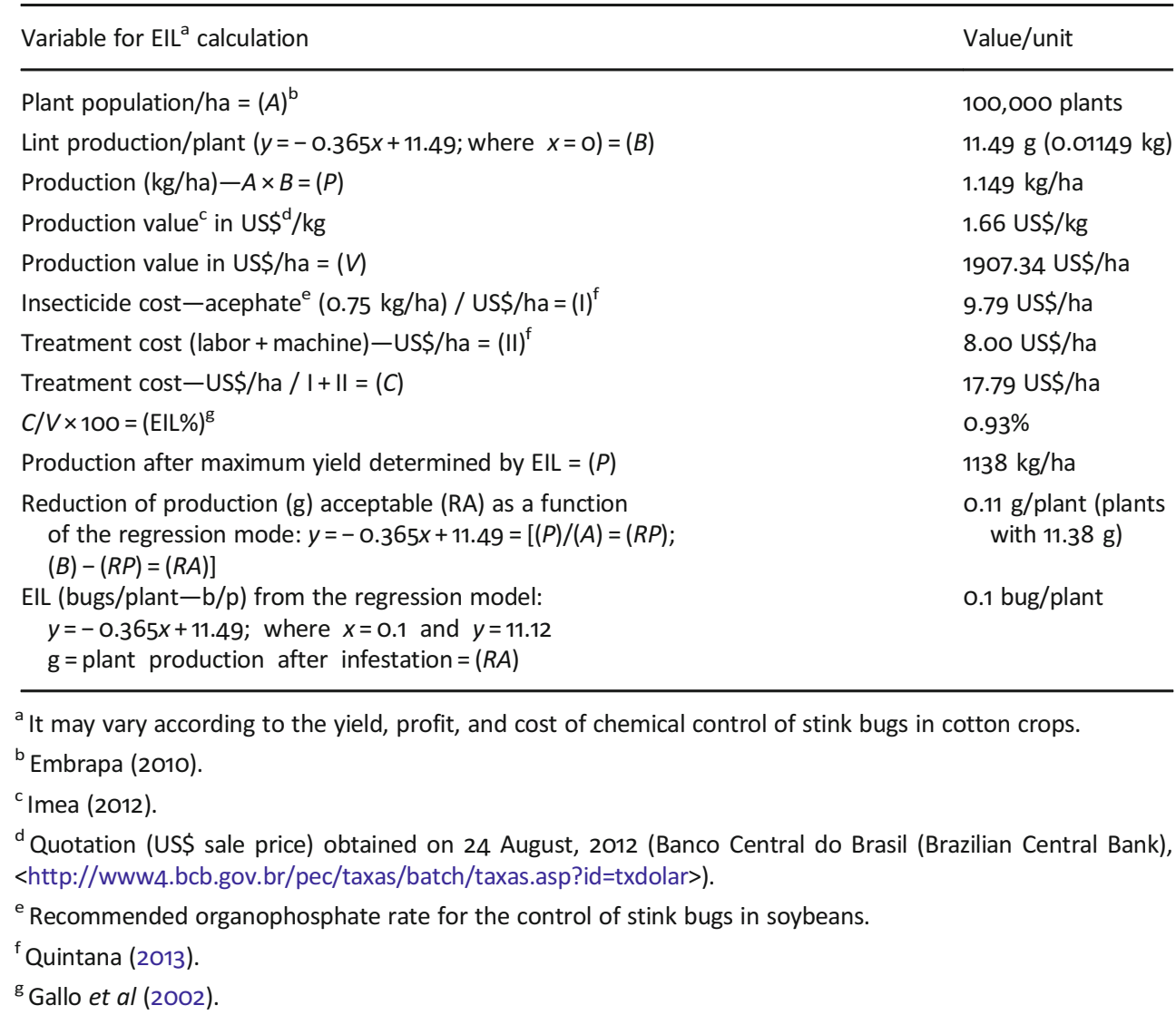

During the period of confinement, the bugs pierced leaves, branches, shoots, buds, flowers, and bolls. Mature bolls were the only structures that were not pierced by these sucking insects, demonstrating the feeding preference of this insect for developing or green plant parts (Panizzi \& Silva 2009).

Phytophagous stink bugs prefer to feed on immature fruits, as penetration by their rostrum and feeding may be easier, and these fruits provide better nutrition (Esquivel 2011, Medrano et al 2011). The bugs of the genus Dysdercus cause injury to cotton plants with open fruits (bolls), and they feed on the maturing cotton seeds within these bolls (Schaefer 1998, Ahmad \& Schaefer 2000, Gallo et al 2002), causing discoloration of fibers due to defecation while feeding. In the present study, this phenomenon was not observed for $E$. heros that infested mature plants with open bolls.

Puncture marks and cell calluses increased proportionally with the increase in the number of insects caged per plant, indicating that a larger number of bolls may suffer attack at a higher infestation level in the cotton field. Studies have shown a strong positive correlation between internal puncture marks and cell calluses ("warts") in the loci of cotton bolls attacked by stink bugs (Blinka et al 2008, Soria et al 2010c, Toews et al 2009), suggesting that these two symptoms can be used to confirm the injuries caused by stink bugs on cotton crops. This confirmation can be conducted by opening fruits with an average diameter $(25 \mathrm{~mm})$ and evaluating the internal symptoms of attack (Bacheler et al 2010).

The number of external puncture marks on the exocarp showed an unstable response to the population level, unlike the linear response of puncture marks and calluses observed on the endocarp, suggesting that this parameter does not represent the actual injury caused by bugs. In contrast, at the strongest population indicator, the number of external signals was significantly reduced. Other authors also suggested that the number of external punctures under the exocarp of bolls is not a reliable parameter by which to determine stink bug injury to cotton, as it requires the opening of the structures for the evaluation of internal injuries (Bundy et al 2000, Bacheler et al 2010).

At the same time, the number of diseased loci with poor opening of mature bolls and stained fibers (hard locks) also increased with infestation level, revealing a significant increase in injury with the increase of the insect population. Locules diseased due to injury by pentatomids are impossible to harvest, in addition to causing the depreciation of quality and yield loss (Willich et al 2004c).

The discolored immature fibers found when assessing bolls for internal injuries indicate that the bug rostrum reached the seeds inside the boll, as the marks formed are caused by seed fluid exudates in response to injury (Medrano 
et al 2011). The transmission of pathogens causing rotten cotton bolls may also be related to the discoloration of the fiber, as specimens uninfected by pathogens did not exhibit stained fibers when healthy bolls were attacked (Medrano et al 2009). Phytophagous stink bugs transmit pathogens capable of causing boll rot (Esquivel et al 2010). Similarly, symbiotic organisms occur naturally in pentatomid populations (Mitchell 2004, Prado et al 2006) and may be responsible for the degree of injury due to attack on cotton plants.

The fiber quality indices (micronaire, yellowness, and percentage of short fibers) were also significantly affected by $E$. heros, as observed for other species of stink bugs (N. viridula, E. servus, and P. guildinii) (Cruz-Júnior 2004, Bommireddy et al 2007). In Brazil, Cruz-Júnior (2004) reported a $12 \%$ reduction in the micronaire index of fibers obtained from bolls infested by $N$. viridula and $P$. guildinii. Speciesspecific differences on potential stink bug damage or the ability to reduce fiber quality parameters are related to the type of attack, duration of attack, phenological stage of the plant (age/boll diameter), and variety (Greene et al 1999, Willrich et al 2004a, b, Ward 2005, Soria et al 2010a, b).

Determining the infestation level is important for integrated crop management, as it minimizes costs and increases the profitability of the grower. Therefore (although not used for the calculation of EIL in the present study), micronaire and yellowness indices may be considered alternative parameters by which to determine EIL, as our (highly significant) regression equations for these parameters in response to different $E$. heros population levels allow such evaluations. Furthermore, fiber quality indices are important for the textile industry, and reductions in these indices can cause depreciation, despite good yields (Fonseca \& Santana 2002, Bommireddy et al 2007). For example, the yellowness index showed the same response as the percentage of locules with immature fibers, indicating some degree of correlation and a relationship between these two parameters.

Studies have shown that adults of $E$. heros are capable of reducing the production of seed cotton by approximately $13 \%$ when feeding on bolls $25 \mathrm{~mm}$ in diameter (Soria et al 2010c). Other studies have shown that the ability of these insects to cause damage is related to the phenology of the cotton plant (Herbert et al 2009, Willrich et al 2004a, b), as the plants can compensate/tolerate damage by producing new fruits. It may also be related to the degree of susceptibility of bolls, as mentioned earlier, as observed with the pentatomid $E$. servus, which caused significant losses in the production of seed cotton of infested plants as function of the flowering week (Willrich et al 2004a).

Using our results, it was possible to determine the EIL for $E$. heros during the boll-filling stage to be 0.5 adult bugs per plant. This level of economic damage should apply to crops that are in the initial 6 weeks of flowering, as most of the fruits of plants in this period are less than or equal to $25 \mathrm{~mm}$ in diameter (Bacheler et al 2010). Considering that the level of control (LC) or treatment threshold is $10-20 \%$ below the EIL, any intervention measure, especially the use of insecticides to reduce populations of $E$. heros on cotton plants to avoid economic losses, should consider that the LC for this species on flowering cotton plants is approximately equal to or less than 0.08 bugs/plant ( $\approx 0.1$ adult bugs/plant).

It is noteworthy that the LC (calculated considering the amount of action required for any control measure adopted by the grower for the insect population to reach the EIL) is below the EIL, as time passes between estimating the pest population (degree of infestation) and the moment of control. Thus, depending on the percentage of security incorporated into the $\mathrm{LC}$ resulting from the EIL, our recommended LC may be close to the values recommended in Australia and the USA for the control of $E$. heros on Bt cotton plants.

The LC of 0.08 bugs per plant is near the recommended level in the USA and Australia, considering a population of 100,000 plants/ha and extrapolating the bug infestation/ plant, despite the fact that the treatment threshold can vary according to the plant stage and stink bug species. In the USA, it is recommended to control pentatomid cotton pests when (on average) one adult stink bug/2 $\mathrm{m}$ is observed (Greene et al 2001). In Australia, control measures are suggested when an average of 0.5 adult bugs/m of crop is observed (Ward 2005), which is determined through the use of beat cloth, similar to the case observed in the present study. Extrapolating the results obtained by Ward (2005) and Greene et al (2001) for the infestation per plant, an EIL between 0.1 and 0.05 bugs per plant is determined, respectively.

In Brazil, monitoring pests on cotton crops is based on the degree of infestation obtained from the number of insects observed or from the assessment of symptoms of injuries on the plants (Degrande 1998). Thus, the LC proposed in this study can only be used for the management of migrant (dispersant) stink bugs on cotton plants in the Cerrado. The beatsheet and sweepnet methods are not yet used in Brazil, although they may be added in parallel with the visual assessment of plants, which has been widely adopted by cotton growers (Degrande et al 2003, Wade et al 2006, Thomazoni et al 2010).

This contrast of different EIL recommendations for stink bugs on cotton plants highlights the need for more studies in this area. Even in countries where this issue already has achieved a certain satisfactory level of response, such as in the USA, investments are made on research for improving the EIL determination for these insect pests in cotton plants. Nevertheless, the results of the present study indicate, for the first time, the level of economic damage by $E$. heros in cotton grown under Brazilian conditions. This approach considered the Cerrado cotton-soy farming system by extrapolating data and predicting the loss of fiber quality and yield by 
evaluating symptoms of internal injuries and the population density of this insect in accordance with the principles of integrated pest management (IPM). Hence, field trials to complement the results obtained in this study are recommended since environmental conditions can interfere in the ability of the plant to compensate injury as well as natural infestations of stink bugs can impact differently on the plants.

In summary, cotton plants in the pre- and early-flowering and full-maturity stages are not affected by infestations of adult $E$. heros. Internal punctures and cell calluses ("warts") on the immature boll mesocarp increase linearly with increasing $E$. heros infestation. External punctures of the epicarp of cotton bolls do not follow a fixed pattern of increase due to the increasing numbers of $E$. heros. The evaluation of external signs of punctures of the epicarp is not a reliable way to estimate the infestation by $E$. heros in cotton. Conversely, the assessment of internal symptoms of injuries in boll mesocarp is valid for this purpose. The percentage of loci with stained immature fibers in bolls attacked by $E$. heros had limited growth, reaching a maximum of $61 \%$ and not following the increase in the population of $E$. heros. The production of seed cotton and fiber is linearly reduced as the population of $E$. heros increases, and losses of 18 and $25 \%$ in the production of seed cotton and fiber, respectively, may occur. The micronaire quality indices and yellowness indices are linearly affected by increased infestation with $E$. heros. The EIL of $E$. heros on cotton plants at the bollfilling stage is 0.1 adult bugs/plant.

Acknowledgments We would like to thank Conselho Nacional de Desenvolvimento Científico e Tecnológico (CNPq) for providing grant to MFS and to A. V. de Lima for his help with the greenhouse work.

\section{References}

Ahmad I, Schaefer CW (2000) Cotton stainers and their relatives (Pyrrhocoroidea: Pyrrhocoridae and Largidae). In: Schaefer CW, Panizzi AR (eds) Heteroptera of economic importance. CRC, Boca Raton, pp 271-307

Bacheler J, Herbert DA, Greene J, Roberts P, Toews M, Blinka E (2010) Scouting for stink bug damage in Southeast cotton: description and use of a pocket scouting decision aid. NC State University A\&T State University Cooperative Extension, Raleigh, $2 \mathrm{p}$

Blinka E, Van Duyn JW, Herbert A, Malone S, Roberts PM, Bacheler JS, Bradley JS (2008) Association of external stink bug-induced cotton boll damage with internal damage, lint yield and quality. In: National Cotton Council (eds) Proceedings of Beltwide Cotton Conferences, Nashville, pp 1110-1115

Bommireddy PL, Leonard BR, Temple JH (2007) Influence of Nezara viridula feeding on cotton yield, fiber quality, and seed germination. J Econ Entomol 100:1560-1568

Bundy CS, McPherson RM, Herzog GA (2000) An examination of the external and internal signs of cotton boll damage by stink bugs (Heteroptera: Pentatomidae). J Entomol Sci 35:402-410
Cruz-Júnior JFA (2004) Danos causados por Nezara viridula (Linnaeus, 1758) e Piezodorus guildini (Westwood, 1837) (Hemiptera: Pentatomidae) em maçãs de algodoeiro (Gossypium hyrsutum L.) [Damage by Nezara viridula (Linnaeus, 1758) and Piezodorus guildini (Westwood, 1837) (Hemiptera: Pentatomidae) on cotton bolls (Gossypium hyrsutum L.)]. Dissertation (Masters in Entomology), Universidade de São Paulo, Piracicaba, $41 \mathrm{p}$

Cruz-Júnior JFA, Nakano O, Romano FCB, Cunha US (2003) Danos causados por Nezara viridula (Linnaeus, 1758) e Piezodorus guildini (Westwood, 1837) (Hemiptera: Pentatomidae) em maçãs de algodoeiro (Gossypium hyrsutum L.) [Damage by Nezara viridula (Linnaeus, 1758) and Piezodorus guildini (Westwood, 1837) (Hemiptera: Pentatomidae) on cotton bolls (Gossypium hyrsutum L.)]. In: Congresso Brasileiro do Algodão (eds) Goiânia-GO, Algodão, um Mercado em Evolução

CONAB (Companhia Nacional de Abastecimento) (2012) Custos de produção - Culturas de Verão. Available at http://www.conab.gov. $\mathrm{br} /$ conteudos.php?a=1276\&t=2\&Pagina_objcmsconteudos $=5 \#$ A objcmsconteudos

DE M Beltrão NE, Fideles Filho J, Figueiredo ICM (2002) Uso adequado de casa-de-vegetação e de telados na experimentação agrícola. Rev Bras Eng Agríc Amb 6:547-552

Degrande PE (1998) Guia prático de controle de pragas do algodoeiro. UFMS, Dourados, $60 \mathrm{p}$

Degrande PE, Vivan LM (2008) Pragas da soja (Soya pests). In: Boletim de Pesquisa de Soja 2008. Carrion \& Carracedo, Rondonópolis, pp 123-160

Degrande PE, de Oliveira MA, Ribeiro JF, Barros R, Nogueira RF, Rodrigues ALL, Fernandes MG (2003) Avaliação de métodos para quantificar predadores de pragas do algodoeiro [Methods for pesticide evaluation: impact on predators of cotton pests]. Arq Inst Biol (Sao Paulo) 70:291-294

Esquivel JF (2011) Estimating potential stylet penetration of southern green stink bug-a mathematical modeling approach. Entomol Exp Appl 140:163-170

Esquivel JF, Medrano EG, Bell AA (2010) Southern green stink bugs (Hemiptera: Pentatomidae) as vectors of pathogens affecting cotton bolls - a brief review. Southwest Entomol 35:457-461

Fonseca RG, Santana JCS (2002) Resultados de ensaio HVI e suas interpretações (ASTM D-4605) [HVI test results and their interpretations (ASTM D-4605)]. EMBRAPA Algodão Techn Rep 66:1-13

Gallo D, Nakano O, Silveira S, Carvalho R, Baptista G, Berti E, Parra JR, Zucchi R, Alves SB, Vendramim JD, Marchini LC, Lopes JS (2002) Entomologia Agrícola. FEALQ, Piracicaba, São Paulo, $920 \mathrm{p}$

Greene JK, Turnipseed SG, Sullivan MJ, Herzog GA (1999) Boll damage by southern green stink bug (Hemiptera: Pentatomidae) and tarnished plant bug (Hemiptera: Miridae) caged on transgenic Bacillus thuringiensis cotton. J Econ Entomol 92:941-944

Greene JK, Turnipseed SG, Sullivan MJ, May OL (2001) Treatment thresholds for stink bugs (Hemiptera: Pentatomidae) in cotton. J Econ Entomol 94:403-409

Greene JK, Bundy CS, Roberts PM, Leonard BR (2006) Identification and management of common boll feeding bugs in cotton. In: Clemson Extension Report, EB158. EUA, Blackville, $28 \mathrm{p}$

Haney PB, Lewis WJ, Lambert WR (2009) Cotton production and the boll weevil in Georgia: history, cost of control, and benefits of eradication. In Research Bulletin of The Georgia Agricultural Experiment Stations/ College of Agricultural and Environmental Sciences. The University of Georgia, Athens, $60 \mathrm{p}$

Herbert A, Blinka E, Bacheler J, Van Duyn J (2009) Managing stink bugs in cotton: research in the southeast region. Virginia Cooperative Extension, Blacksburg, $444 \mathrm{p}$

Medrano EG, Esquivel JF, Nichols RL, Bell AA (2009) Temporal analysis of cotton boll symptoms resulting from southern green stink bug feeding and transmission of a bacterial pathogen. J Econ Entomol 102:3642 
Medrano EG, Esquivel JF, Bell AA, Greene JK, Roberts PM, Bacheler JS, Marois JJ, Wright DL, Nichols RL (2011) Analysis of microscopic injuries caused by southern green stink bug (Hemiptera: Pentatomidae) feeding on cotton bolls. Southwest Entomol 36:233-245

Mitchell PL (2004) Heteroptera as vectors of plant pathogens. Neotrop Entomol 33:519-545

Musser F, Knighten KS, Reed JT (2008) Comparison of cotton damage from tarnished plant bug (Hemiptera: Miridae) and Southern green stink bug (Hemiptera: Pentatomidae) adults and nymphs. Midsouth Entomol 2:1-9

Olson DM, Ruberson JR, Zeilinger AR, Andow DA (2011) Colonization preference of Euschistus servus and Nezara viridula in transgenic cotton varieties, peanut, and soybean. Entomol Exp Appl 139:161-169

Panizzi AR (1997) Wild host of pentatomids: ecological significance and role in their pest status on crop. Annu Rev Entomol 42:99-122

Panizzi AR (2000) Suboptimal nutrition and feeding behavior of hemipterans on less preferred plant food sources. Anais Soc Entomol Bras 29:1-12

Panizzi AR, Silva FAC (2009) Insetos sugadores de sementes (Heteroptera) [Seed sucking insects (Heteroptera)]. In: Panizzi AR, Parra JRP (eds) Bioecologia e nutrição de insetos. Base para o Manejo Integrado de Pragas. Embrapa Informação Tecnológica, Londrina, pp 465-522

Prado SS, Rubinoff D, Almeida RPP (2006) Vertical transmission of a pentatomid caeca-associated symbiont. Ann Entomol Soc Am 99: 577-585

Quintana AC (2013) Agrianual 2013: Anuário Estatístico da Agricultura Brasileira. FNP Consultoria \& Comércio, São Paulo, $480 \mathrm{p}$

Reay-Jones FPF, Greene JK, Toews MD, Reeves RB (2009) Sampling stink bugs (Hemiptera: Pentatomidae) for population estimation and pest management in southeastern cotton production. J Econ Entomol 102: 2360-2370

Ritchie GL, Bednarz CW, Jost PH, Brown SM (2007) Cotton growth and development. The Georgia Agricultural Experiment Stations/College of Agricultural and Environmental Sciences, Athens, $16 p$

SAS Institute (2008) SAS/STAT ${ }^{\circledR}$ 9.2: user's guide. SAS Institute, Cary

Schaefer CW (1998) Notes on Dysdercus from Brazil (Hemiptera: Pyrrhocoridae). Anais Soc Entomol Bras 27:485-488

Siebert MW, Leonard BR, Gable RH, Lamotte LR (2005) Cotton boll age influences feeding preference by brown stink bug (Heteroptera: Pentatomidae). J Econ Entomol 98:82-87

Soria MF, Degrande PE (2015) Manejo Integrado de pragas no algodoeiro em Mato Grosso. In: Manual de Boas Práticas de Manejo do Algodoeiro em Mato Grosso - Safra 2014/15. Editora Casa da Árvore, Cuiabá, pp 178-202
Soria MF, Thomazoni D, Martins RR, Degrande PE (2009) Stink bugs incidence on Bt cotton in Brazil. In: National Cotton Council (eds) Proceedings of Beltwide Cotton Conferences. EUA, San Antonio, pp 813-819

Soria MF, Degrande PE, Panizzi AR, Brewer MJ (2010a) Heteropterans pests of cotton in the Brazilian Cerrado. In: Entomological Society of America Proceedings (eds) The $58^{\text {th }}$ Annual Meeting of the Entomological Society of America. EUA, San Diego

Soria MF, Degrande PE, Panizzi AR (2010b) Potencial de dano do percevejo-marrom neotropical Euschistus heros (F.) em maçãs de algodoeiro Bt e não-Bt de diferentes idades [Potential damage of the neotropical brown stink bug Euschistus heros (F.) on bolls of $\mathrm{Bt}$ and non-Bt cotton of different ages]. In: Natal-RN (ed) XXIII Congresso Brasileiro de Entomologia

Soria MF, Degrande PE, Panizzi AR, Thomazoni D, Kodama C, Azambuja T (2010c) Neotropical brown stink bug Euschistus heros (Fabr., 1798) Attack on Bt-cotton bolls cultivated in Brazilian savannah. In: National Cotton Council (eds) Proceedings of Beltwide Cotton Conferences. EUA, New Orleans, pp 978-984

Thomazoni D, Degrande PE, Silvie P, Faccenda O (2010) Impact of Bollgard genetically modified cotton on the biodiversity of arthropods under practical field conditions in Brazil. Afr J Biotechnol 9:6167-6176

Toews MD, Blinka EL, Van Duyn JW, Herbert DA, Bacheler JS, Roberts PM, Greene JK (2009) Fidelity of external boll feeding lesions to internal damage for assessing stink bug damage in cotton. J Econ Entomol 102:1344-1351

Wade MR, Scholz BCG, Lloyd RJ, Cleary AJ, Franzmann BA, Zalucki MP (2006) Temporal variation in arthropod sampling effectiveness: the case for using the beat sheet method in cotton. Entomol Exp Appl 120:139-153

Ward AL (2005) Development of a treatment threshold for sucking insects in determinate Bollgard II transgenic cotton grown in winter production areas. Aust J Entomol 44:310-315

Wene GP, Sheets LW (1964) Notes on and control of stink bugs affecting cotton in Arizona. J Econ Entomol 57:60-62

Willrich MM, Leonard BR, Gable RH, Lamotte LR (2004a) Boll injury and yield losses in cotton associated with brown stink bug (Heteroptera: Pentatomidae) during flowering. J Econ Entomol 97:1828-1834

Willrich MM, Leonard BR, Temple J (2004b) Injury to preflowering and flowering cotton by brown stink bug and southern green stink bug. J Econ Entomol 97:924-933

Willrich MM, Leonard BR, Padgett GB (2004c) Influence of southern green stink bug, Nezara viridula L., on late-season yield losses in cotton, Gossypium hirsutum L. J Econ Entomol 33:1095-1101 